\title{
STUDIES ON LEUKOCYTE ADHERENCE INHIBITION TEST \\ PART II. CLINICAL APPLICATION OF LAI TEST TO DETECT DELAYED TYPE HYPERSENSITIVITY IN INFANTS AND CHILDREN
}

\author{
TADATOSHI KURATSUJI \\ Department of Pediatrics, School of Medicine, Keio University, \\ Tokyo, Japan
}

(Received for publication November 12, 1980)

\begin{abstract}
The leukocyte adherence inhibition (LAI) test were performed by utilizing Halliday's hemacytometer method. Total 47 healthy individuals (4 tuberculin purified protein derivative-positive, 12 Candida-positive, 8 house dust-positive and 23 delayed skin test-negative), aged 3 weeks to 6 years old, were blood donors. Mononuclear leukocytes (MNL) were isolated from the peripheral blood, and used as effector and indicator cells. Mean percent leukocyte adherence inhibition (\% LAI) of MNL from persons with positive delayed skin test is $34.78 \pm 12.40$. When skin test is negative, mean \% LAI is $9.64 \pm 8.20$. There is a significant difference between them. $(p<0.001)$ The LAI test seems to be usable to detect cell-mediated immunity, especially in infants and children, partly because only a small volume of blood is required to the LAI test.
\end{abstract}

\section{INTRODUCTION}

The physical and mental status in infants and children is still underdeveloped. Infants or children are more susceptible to infections than adults, because their host defence mechanisms are also still at the developing stage. ${ }^{1}$ Humoral immunity in children has been well studied. Therefore many immunization systems are almost completed to protect children from polyomyelitis, diphtheria, pertussis, tetanus and so on. ${ }^{2}$ On the other hand, development of cell-mediated immunity is still unclear, partly because there is a discrepancy between the skin test and lymphokine production of the $\mathrm{T}$ cells. ${ }^{3}$

In infants, the efferent limb (that is granulocyte and monocyte chemotaxis) 
is impaired, but the efferent limb (that is $\mathrm{T}$ cell function) seems to be almost normal. Tests for in vitro lymphokine production requires a large volume of blood lymphocytes, so this is a large burden to the infants. Since the circulatory blood volume of children is limited, we must examine only the essential, effective tests by using a minimum amount of blood. The LAI test reported by Halliday in 1972 is evaluated as a test to detect the blocking factor and is applyed in clinical medicine.

The LAI test offers two benefits, first, only a very small volume of blood is required, second, the result is known in a short period.

In Part I, the LAI test was reported as an expression of cell-mediated response by utilizing the guinea pig system. This study is to see whether the LAI test is usable to detect CMI in infants and children.

\section{MATERIALS AND METHODS}

Mononuclear cell : 47 healthy individuals (4 PPD-positive, 12 candida-positive, 8 house dust-positive, 23 skin test-negative), aged 3 weeks to 6 years old, were blood donors. Mononuclear cells were isolated from the peripheral blood by means of density centrifugation. 1-2 $\mathrm{ml}$ of heparinized blood were layered over $3 \mathrm{ml}$ Ficoll-Conray solution and centrifuged at $450 \mathrm{~g}$ for $20 \mathrm{~min}$. The cells from a white band of the interface were washed and resuspended in Eagle's essential medium containing $10 \%$ heat-inactivated fetal calf serum at the concentration of $1 \times 10^{6} \mathrm{cell} / \mathrm{ml}$. Differential cell count of this cell suspension showed $85-98 \%$ to be lymphocytes, $15-2 \%$ monocytes.

Skin test: Skin tests were done, intradermally with 100 i.u. of PPD (Nippon BCG Institute), $0.1 \mathrm{ml}$ of $1: 1000$ solution of Candida broth (Immunodeficiency Syndrome Research Committee of the Ministry of Health and Welfare) or $0.1 \mathrm{ml}$ of 1:1000 solution of house dust antigen (Torii Co.), and the induration was read after 48 hours.

LAI test: The LAI test was examined by a modified Halliday's hemacytometer method described in Part I of this study. Briefly, $100 \mu$ l of cell suspension in RPMI-FCS was incubated with $10 \mu$ of the specific or unrelated antigen solution in a plastic tube for $30 \mathrm{~min}$., and thereafter in a non-metalized, acid-treated Neubauer chamber for another $90 \mathrm{~min}$. at $37^{\circ} \mathrm{C}$ in a humidified atmosphere of $5 \% \mathrm{Co}_{2}$-air. Cells were counted in each mixture in a predetermined pattern. The remaining cells after rinsing the slide chamber were counted in the same squares again. The results were estimated as a percent of leukocyte adherence inhibition (\% LAI). Each test was done in triplicated. The resulting value was expressed as means of three chambers \% LAI \pm standard deviations.

The stastical significance of the difference in LAI between skin test positive 
and negative patients was determined using the Student's $t$ test.

\section{RESULTS}

1) Delayed type hypersensitivity to Candida, PPD and House dust (H.D.).

The percent of leukocyte adherence inhibition from patients with delayed hypersensitivity was markedly increased by adding the specific antigen. (Fig. 1) Although the extent of \% LAI could not be directly correlated with the diameter of the skin reaction, (Table 1) there was in general a close parallel between LAI and DTH except in a few cases. The dose of Candida and HD required in this study was smaller than that of PPD, but the reactions were successful.

\section{2) Antigen specificity of LAI.}

Skin reactions by two kind of antigens (Candida and PPD) were examined in several patients, and the LAI test was performed. The human serum albumin was used as a control antigen. PPD was also used as a control (unspecific) antigen when the PPD skin test was negative, and vice versa. As shown in Table 2, when a patient's skin test of Candida was positive and PPD negative, \% LAI between Candida and PPD was high, and between PPD and HSA was low.

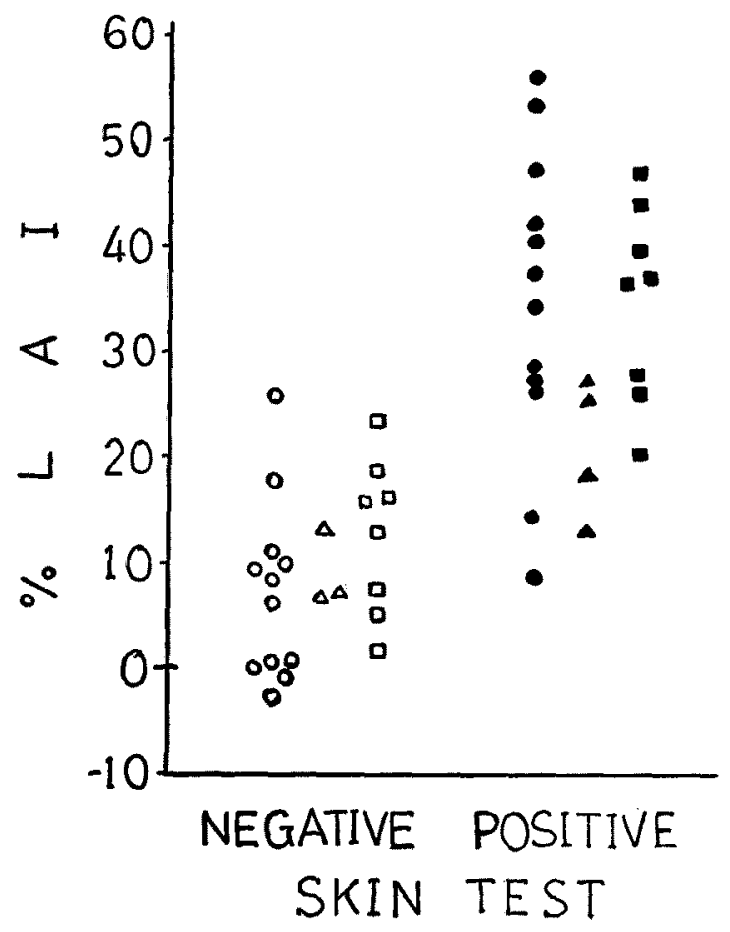

Fig. 1 Leukocyte adherence inhibition phenomena in humans. Filed symbols represent skin test positive individuals and open symbols represent skin test negative.

0,0 : Candida, $\triangle, \triangle: P P D$ and 已, : House Dust. 
Table 1

Relationship between delayed type skin test and leukocyte adherence inhibition test

\begin{tabular}{c|c|c|c|c|r}
\hline \hline $\begin{array}{c}\text { Patient } \\
\text { No. }\end{array}$ & Skin Test* & $\%$ LAI & $\begin{array}{l}\text { Patient } \\
\text { No. }\end{array}$ & Skin Test & $\%$ LAI \\
\hline 1 & $15 \times 15$ & 56.0 & 13 & $0 \times 0$ & 8.6 \\
2 & $20 \times 22$ & 53.2 & 14 & $0 \times 0$ & 1.1 \\
3 & $11 \times 14$ & 47.3 & 15 & $0 \times 0$ & 0.0 \\
4 & $15 \times 15$ & 42.0 & 16 & $0 \times 0$ & -0.2 \\
5 & $20 \times 20$ & 40.5 & 17 & $1 \times 1$ & 0.7 \\
6 & $20 \times 26$ & 37.8 & 18 & $1 \times 1$ & -2.5 \\
7 & $11 \times 18$ & 34.5 & 19 & $2 \times 1$ & 6.0 \\
8 & $16 \times 23$ & 28.1 & 20 & $0 \times 0$ & 9.6 \\
9 & $15 \times 15$ & 27.3 & 21 & $0 \times 0$ & 9.9 \\
10 & $10 \times 10$ & 26.3 & 22 & $0 \times 0$ & 11.5 \\
11 & $12 \times 12$ & 14.0 & 23 & $0 \times 0$ & 25.6 \\
12 & $10 \times 12$ & 8.8 & 24 & $0 \times 0$ & 17.6 \\
\hline
\end{tabular}

* Candida was used as the antigen, $0.1 \mathrm{~m}$ of $1: 1000$ solution of Candida broth was injected intradermally and the diameter $(\mathrm{mm})$ of skin reaction was read 48 hours after.

Significant difference between normal and Candida-sensitive;

$\mathrm{P}=<0.001$ (Student $\mathrm{t}$-test).

Table 2

Antigen specificity of leukocyte adherence inhibition

\begin{tabular}{|c|c|c|c|c|c|c|}
\hline \multirow{2}{*}{$\begin{array}{l}\text { Patient } \\
\text { No. } \\
3\end{array}$} & \multicolumn{2}{|c|}{$\begin{array}{l}\text { Skin Test } \\
\text { Candida, PPD }\end{array}$} & \multicolumn{4}{|c|}{$\begin{array}{l}\text { Percent Leukocyte Adherence Inhibition } \\
\text { Candida/HSA, PPD/HSA, Candida/PPD, PPD/Candida }\end{array}$} \\
\hline & + & + & $47.3^{*}$ & 13.0 & & \\
\hline 7 & + & + & 34.5 & 25.8 & & \\
\hline 5 & + & - & 40.5 & 7.3 & 35.8 & \\
\hline 6 & + & - & 37.8 & 13.3 & 28.3 & \\
\hline 8 & + & - & 28.1 & 7.3 & 22.4 & \\
\hline 13 & - & + & 8.6 & 27.5 & & 20.7 \\
\hline 14 & - & + & 1.1 & 18.5 & & 17.6 \\
\hline
\end{tabular}

+ : Positive skin test to Candida or PPD.

- : Negative skin test to Candida or PPD.

*: Average of \% LAI.

When skin tests of Candida and PPD were both positive, \% LAI between Candida and HSA, and between PPD and HSA were positive. 


\section{DISCUSSION}

It is important that we estimate cell-mediated immune status in order to examine and treat infants and children. The specificity and reproducibility of the tests for DTH in vitro such as MIF, mitogenic, lymphotoxin test, and so on are confirmed by many investigators, but these tests require a large volume of blood lymphocytes, excellent technique and from one to seven or more days to complete. Thus these are not good tests for children. The LAI test described by Halliday and Miller in 1972, ${ }^{4}$ was clarified as an expression of cell-mediated immune response in the Part $I$ of this study.

The LAI test was put to clinical use. The results of the present study showed that the extent of the LAI phenomenon did not correlate with the diameter of delayed type skin reaction, but that the LAI was specific for the antigen of DTH. The LAI test seems to be a useful test not only to detect the serum blocking factor in cancer patients, ${ }^{4}$ but also to detect DTH or CMI in children.

\section{SUMMARY}

The adherence of peripheral leukocytes from persons with delayed hypersensitivity to tuberculin purified prontein derivative, Candida or house dust is inhibited by the specific antigen. This phenomenon is specific. The leukocyte adherence inhibition test seems to be usable to detect cell-mediated immunity.

\section{ACKNOWLEDGEMENT}

I wish to thank Prof. Yasuo Ichihashi and Prof. Takeshi Yoshida for their advice. This work was supported by a grant from the Keio University School of Medicine in 1978. This work was presented at the 27th Annual Meeting of the Japtnese Society of Allergology.

\section{REFERENCES}

1. Vaughan, V.C.: Developmental Pediatrics, in "Textbook of Pediatrics". Edited by Vaughan, V.C., Mckay, R.J. and Behrman, R.E., W. B. Saunders Co., Philadelphia 1979, 10-172

2. Haggerty, R. J.: Preventive Pediatrics, in "Textbook of Pediatrics". Edited by Vaughan, V. C., Mckay, R. J. and Behrman, R.E., W. B. Saunders Co., Philadelphia $1979,238-249$

3. Host defense in the human neonate. Edited by Miller M. E. Grune \& Stratton N.Y., 1978

4. Halliday, W.J. and Miler, S.: Leukocyte adherence inhibition: A simple test for cell-mediated immunity and serum blocking factor. Int. J. Cancer 9: 477-483, 1972 